International Business and Global Economy 2017, no. 36, pp. 47-59

Biznes międzynarodowy w gospodarce globalnej 2017, nr 36, s. 47-59

Edited by the Institute of International Business, University of Gdańsk

ISSN 2300-6102

e-ISSN 2353-9496

DOI 10.4467/23539496IB.17.003.7451

Jan Wedemeier

Hamburg Institute of International Economics

\title{
Innovation capabilities of the Baltic Sea region: Meeting Europe 2020 innovation targets? ${ }^{1}$
}

The paper analyses the innovation capabilities and development of the Baltic Sea region within the framework of the Europe 2020 strategy. The ongoing structural change towards service and knowledge societies, innovations, and the increasing integration of markets will have considerable influence on the European Union. In March 2010, the European Commission presented the Europe 2020 strategy, which is supposed to push the EU to become the smartest and most competitive region in the world. Among the EU member states, the Baltic Sea countries are effective in bringing up innovative solutions and establishing cooperation between science and business. However, the Europe 2020 strategy sets ambitious goals and some of the Baltic Sea countries will presumably fail to meet them. The enormous disparities between the countries and between central and peripheral regions within a country can thus be observed in selected indicators. These findings need to be recognised to intensify the efforts to transform the region into an innovation leader.

Keywords: innovation, Baltic Sea region, Europe 2020

JEL classification: O3, R11, R12

\section{Potencjał innowacyjny regionu Morza Bałtyckiego -} spełnienie europejskich celów w zakresie innowacyjności na 2020 r.?

\begin{abstract}
Niniejsza praca analizuje potencjał innowacyjny i rozwojowy regionu Morza Bałtyckiego w ramach strategii Europa 2020. Obecne zmiany strukturalne w społeczeństwach usług i wiedzy, innowacje oraz rosnąca integracja rynków będą miały znaczny wpływ na Unię Europejską. W marcu 2010 r. Komisja Europejska opublikowała strategię Europa 2020, która ma uczynić z UE najbardziej inteligentny i konkurencyjny region na świecie. Wśród krajów członkowskich kraje bałtyckie skutecznie realizują innowacyjne rozwiązania, wspierając jednocześnie współpracę pomiędzy nauką a biznesem. Strategia Europa 2020 formułuje jednak bardzo ambitne cele, których pewnym krajom bałtyckim może nie udać się osiągnąć. Ocena stopnia spełnienia wybranych wskaźników ukazuje ogromne różnice geograficzne pomiędzy północą i południem oraz wschodem i zachodem, jak również pomiędzy terenami metropolitalnymi a peryferyjnymi. Należy zwrócić uwagę na wyniki badań, gdyż mogą one przyczynić się do wejścia regionu do innowacyjnej czołówki.
\end{abstract}

Słowa kluczowe: innowacja, region Morza Bałtyckiego, Europa 2020

Klasyfikacja JEL: O3, R11, R12

1 The author would like to express his gratitude to Mirko Kruse for helpful support, suggestions, and corrections. He is also grateful to anonymous referees for their ideas and opinions. 


\section{Introduction}

In March 2010, the European Commission put the Europe 2020 strategy on the political agenda, which shall give Europe a growth impulse to become the smartest and most competitive region in the world. It envisions Europe as a social market economy of the $21^{\text {st }}$ century - smart, sustainable, and inclusive ${ }^{2}$. Five headline targets serve as benchmarks for the EU 2020 strategy on employment, education, social inclusion, $R \& D$, and climate and energy. The main drivers of the European 'Innovation Union' are presumably the Scandinavian countries and Germany. Therefore, it is of interest to focus on the development of the Baltic Sea region and see if it can become the most innovative (macro) region within the European Union.

The Baltic Sea region comprises eleven countries: Belarus, Norway, and Russia, and eight EU member states: Denmark, Sweden, Finland, Estonia, Lithuania, Latvia, Poland, and Germany. Germany is the largest member state ( 82.2 million inhabitants), and Estonia is the smallest (1.3 million inhabitants). Together, these eight countries account for ca. 29\% (147 million inhabitants) of the European population and generate ca. $30 \%$ of the GDP of the $\mathrm{EU}^{3}$. This makes the region a significant economic centre in Europe, whose specific structure and history offer enormous opportunities for development.

The ongoing structural change towards, i.a., service and knowledge societies, innovations, and the increasing integration of markets will have considerable influence on the Baltic Sea region. But how can the development of its innovation capabilities in respect of the EU-2020 strategy be evaluated? The Baltic Sea region countries are effective in bringing up innovative cluster solutions, encouraging cooperation between science and business, and supporting the R\&D sector from the GDP. They are supporters of green growth, based on innovation policy and a stronger turn to renewable energy sources. These are aspects of strategic significance, which is reflected by the EU-2020 strategy headline indicators [EC, 2009; Stiller, Wedemeier, 2016].

In the first section of this paper, some statistical facts about the Europe 2020 $R \& D$ target are discussed and its relevance for economic development is empha-

2 The European Commission identified seven flagship initiatives to catalyse the attainment of the priorities: 'Innovation Union', 'Youth on the move', 'A digital agenda for Europe', 'Resource efficient Europe', 'An industrial policy for globalisation era', 'An agenda for new skills and jobs', and 'European platform against poverty' [EC, 2010]. Complementary to the EU 2020 strategy, the Commission developed a macro-regional strategy for the Baltic Sea region - the first macro-regional strategy in Europe - to support its implementation [EC, 2009].

3 A more narrow definition of the Baltic Sea region (program) includes the federal states of Berlin, Brandenburg, Bremen, Hamburg, sub-region Lüneburg, Mecklenburg-Western Pomerania, and Schleswig-Holstein for Germany, and the remaining seven countries in the Baltic Sea region in their entirety. This area accounts for 85 million inhabitants of the Baltic Sea region. 
sised. Section 2 presents various descriptive statistics for regional R\&D expenditure and further relevant innovation input indicators. The consulted statistics help to observe the regional fragmentation not only between, but also within the countries. The paper is closed with some conclusions.

\section{Innovation in the Baltic Sea region}

The headline indicators for innovation are, at the same time, ambitiously defined targets. Innovations are crucial for further economic development and prosperity. According to endogenous growth theory, R\&D investments are essential drivers of growth. In the model developed by Paul Romer [1986], the R\&D sector constantly develops new interim products, which leads to a continual increase of productivity ${ }^{4}$. The level of intramural research and development expenditure influences GDP growth; expenditures on R\&D promote innovations that result in economic growth and increased welfare. Developing its technological capabilities and innovation potential is therefore an important prerequisite for the Baltic Sea region to compete with other regions in the global market.

These measures, however, reflect the degree to which conditions are conducive to innovations rather than innovativeness itself. R\&D activity and number of employees in R\&D are common input factors in innovation processes. These differing conditions are reflected in the indicators found in international comparative analyses as well as in the EU 2020 strategy. It should be noted that invention emerges here as an idea for a new product or process, while innovation is the next step, which is to bring the idea into the market [Fagerberg, 2009]. In the knowledge-based European society, many jobs require relatively high qualifications. One Europe 2020 target is to increase the share of population aged 30-34 with completed tertiary education to at least $40 \%$. With the exception of Germany, this will be achieved by all Baltic Sea region countries. In the Scandinavian countries, for instance, this share is traditionally higher than the EU average (39\%; more than 50\% in Sweden), whereas it is the lowest in Germany (32\%) due to its system of vocational training [Stiller, Wedemeier, 2016].

In 2014, the $28 \mathrm{EU}$ member states achieved the ratio of gross domestic expenditure on research and development (GERD) to GDP of 2.03\% [Eurostat, 2016]. It will be a considerable challenge to meet the target of at least $3 \%$ by 2020 . Generally speaking, the Baltic Sea region countries occupy a stable position among the most innovative members of the EU. In 2014, the EU member states with the highest

4 One limitation of the regional patent statistics is that they are based on the place of residence of the inventor, which is not always the same as the place of the invention. The discrepancy is even higher in the case of smaller geographical units. 
(total intramural) ratio of GERD to GDP were Finland (3.2\%) and Sweden (3.2\%), followed by Denmark (3.05\%). In Germany, this ratio reaches ca. 2.9\%, which is still four times higher than the expenditures on R\&D of Latvia, the lowest in the EU. However, the ratio of GERD to GDP in EU partner countries, such as Norway and Russia (1.7\% and $1.2 \%$, respectively), is close to the EU-28 average (2.0\%). Finland's and Sweden's target ratio for 2020 is 4.0\%, Denmark's, Estonia's, and Germany's $-3 \%$, Latvia's $-1.5 \%$, and Lithuania's $-1.9 \%$. These collective European R\&D efforts are somewhat ambitious and, with the exception of Denmark and Germany, most countries will presumably fail to meet their national objectives.

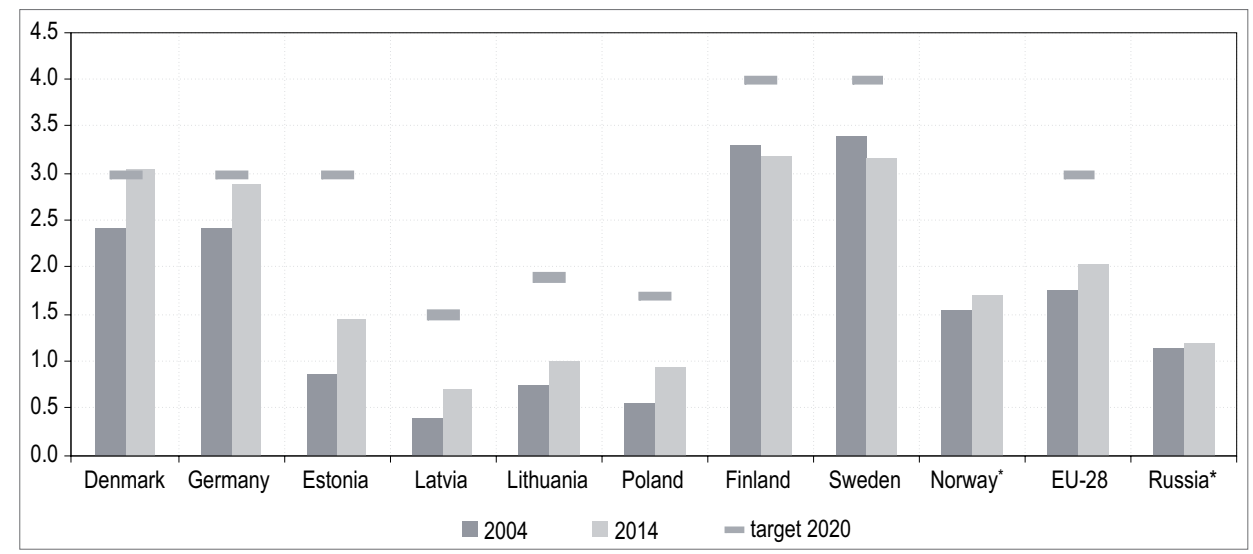

Figure 1. Europe 2020: Gross expenditure on R\&D (in \%)

Notes: Data for Belarus not reported; * partner countries - no targed defined

Source: [Eurostat, 2016].

With regards to Romer's theory, it is worthwhile to look at current GDP growth and R\&D performance. We used R\&D performance as an initial variable to examine its influence on GDP growth. The relation is positive and relatively strong ( $2=0.79$ in logistic regression). The countries under analysis can be divided into two groups. The first group consists of those EU members with an already high GDP (Sweden, Finland, and Germany), which show a relatively low GDP growth and a relatively high level of gross domestic expenditure on research and development. The second group consists of countries that have high GDP growth, but a relatively low level of gross domestic expenditure on R\&D (both in absolute terms and as a ratio to GDP). Figure 2 presents the GDP growth and R\&D investment gap between the less and more developed countries of the Baltic Sea region. It can be assumed that for the more developed Baltic Sea countries it is a fortiori essential to invest more in R\&D to remain globally competitive. This assumption is confirmed, i.a., by Pelle [2015], who demonstrates a positive correla- 


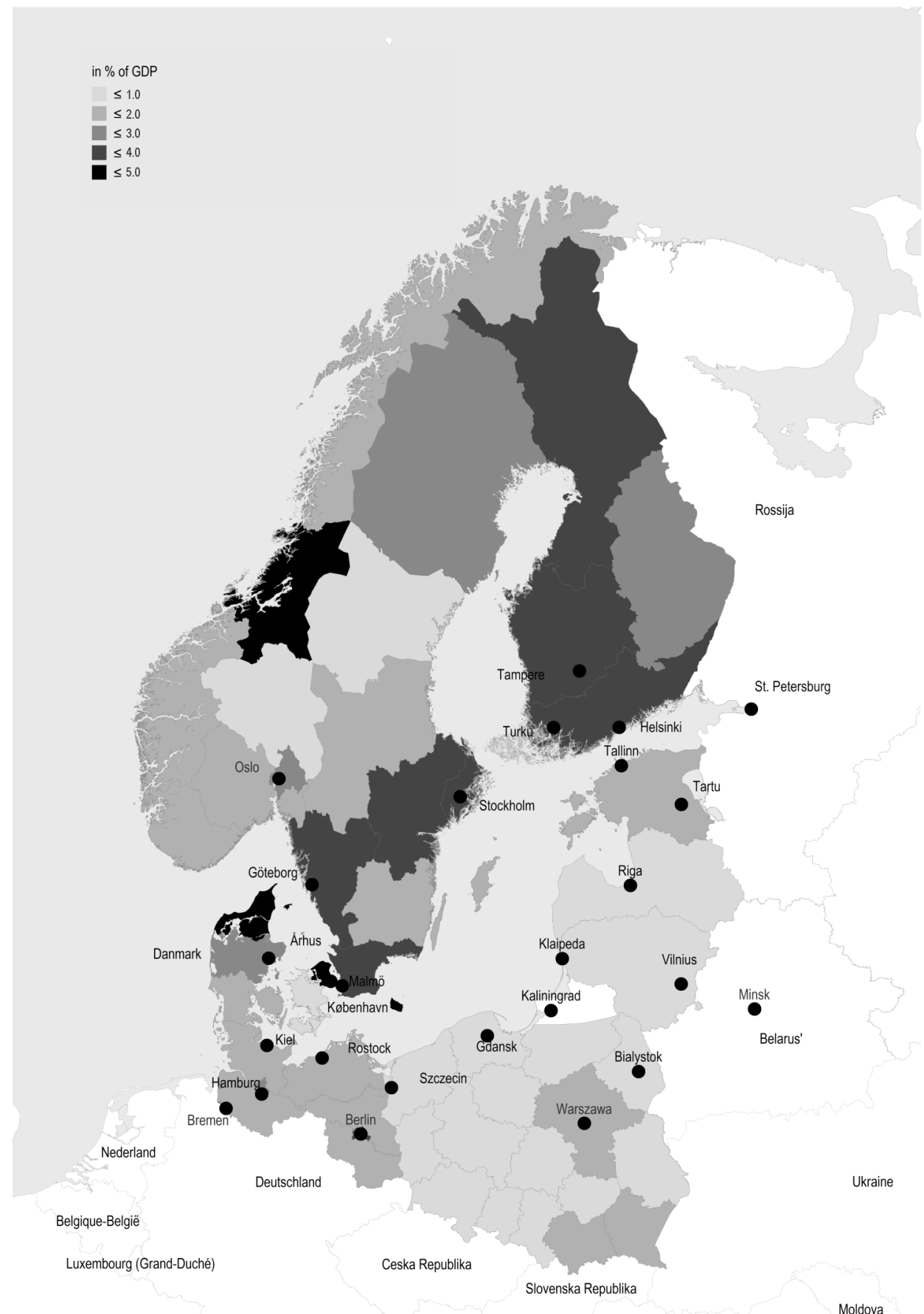

Figure 2. GDP growth in 2000-2014 to GERD in $2000(\%)$

Source: [Eurostat, 2016]. 
tion between R\&D expenditures and the GCI score of EU member states as an indicator of competitiveness. Furthermore, Frietsch, Rammer, and Schubert [2015] state that the poorly developed R\&D industry in Eastern European countries (Poland, Latvia, and Lithuania) is less an outcome of underinvestment than it is a political response to a relatively low capital-output ratio. In other words, there are no considerable research capabilities to catalyse higher expenditures on R\&D. Moreover, it is obvious that, for instance, Norway's GDP growth is driven by other factors, such as the petroleum industry, rather than R\&D expenditures. However, simple regression does not explain causality, nor does it control for the presence of third variables (e.g. industrial classification). In addition, considerable time lags can be observed between the implementation of a marketability innovation and its contribution to the overall economic growth, which are even larger for investments in research and development.

\section{Regional innovation development}

A comparison of the 2013 data on the ratio of GERD to GDP at NUTS 2 level shows that it was the highest in the Copenhagen area (Hovedstaden), followed by Trondelag in Norway and Nordjylland in Denmark (more than $4.6 \%$ each), and the lowest in the Polish voivodships lubuskie and opolskie (ca. 2.6\%). Considerable regional disparities were observed, especially in the Baltic Sea regions with a specialisation and clusters, such as the Danish region of Hovedstaden (i.a. health and food), the Norwegian region of Trondelag (i.a. education and knowledge creation), and the German regions of Bremen (i.a. transportation and logistics) and Hamburg (i.a. transportation, logistics, and distribution) [Eurostat, 2016]. Another typical pattern emerged, namely that the highest level of intramural R\&D expenditures was recorded in capital city regions [Eurostat, 2016]. In Germany, the ratio of GERD to GDP was the highest in Berlin (3.6\%), which was outperformed by several other federal states not included in the Baltic Sea program, such as Braunschweig (7.3\%) and Stuttgart (6\%). In the context of innovation development, it is of great importance, especially for small countries, to focus on their strengths and profile themselves accordingly. Specializing means finding a niche; however, for specialties to develop, it is vital that the necessary critical mass of specialists and human resources in general is reached [Blech et al., 2009]. For small countries, another key to success in forming clusters and maximizing economies of scale is cooperation, which helps to explain the relative openness of, i.a., Denmark and Estonia. 


\begin{tabular}{|c|c|c|c|c|c|c|c|c|c|c|c|c|}
\hline \multirow{2}{*}{\multicolumn{2}{|c|}{ 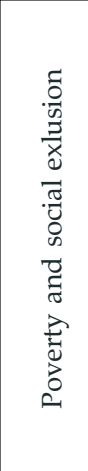 }} &  & 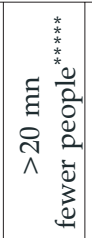 & & $\stackrel{3}{\stackrel{2}{2}}$ & ¿̊ำ & & & ف․ & & ڤn: & \\
\hline & & 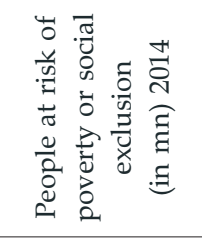 & ه̊ & & : & 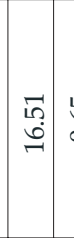 & & & 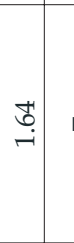 & & $\stackrel{\infty}{\circ}$ & 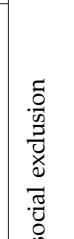 \\
\hline & 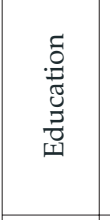 & 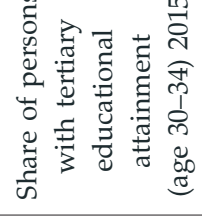 & $\begin{array}{l}\text { I } \\
\wedge\end{array}$ & & 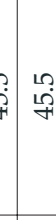 &  & 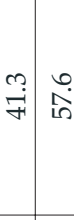 & 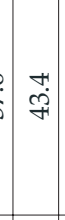 & ณี & {$\left[\begin{array}{c}\infty \\
\infty \\
\infty\end{array}\right.$} & &  \\
\hline & 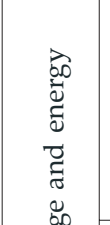 & 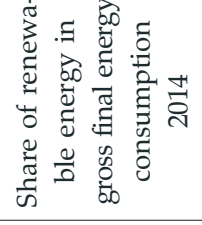 & ষ্ণ் & & & & & 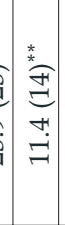 & 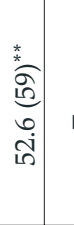 & & 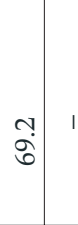 &  \\
\hline & 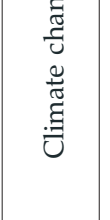 & 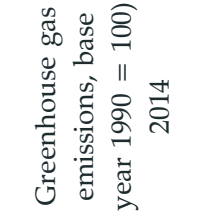 & 怘 & & 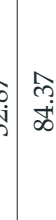 & 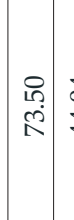 & & 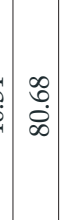 & 足 & 总 & &  \\
\hline & 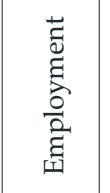 & 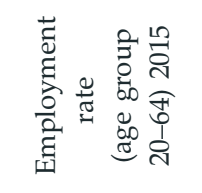 & 㤐 &  & i & & & $\mid$ & 然 & & $\overrightarrow{L^{\prime}}$ & 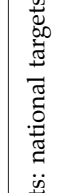 \\
\hline & 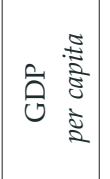 & 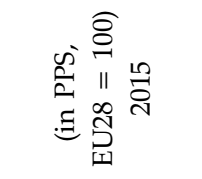 & 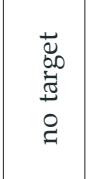 & $\overrightarrow{\mathrm{g}}$ & 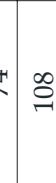 & $\stackrel{2}{\mathfrak{a}}$ & & 8 & $\mathbb{\Xi}$ & 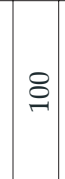 & $:$ & $\because \bar{z}$ \\
\hline & & 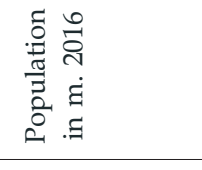 &  &  & & $\begin{array}{c}\underset{\infty}{1} \\
\infty\end{array}$ & ci & 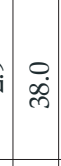 & 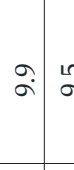 & is & 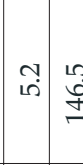 & \\
\hline & & & 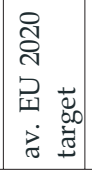 & 意 & & & & & का) & 更 & 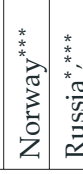 & \\
\hline
\end{tabular}


Sweden, Finland, Denmark, and Germany are among the leading 'inventors' in Europe and file more patents than the EU average. In contrast, patents play a secondary role in innovation development in Russia and the more recent EU members, such as Estonia [Stiller, Wedemeier, 2016], which witnessed over 50\% decline in the number of patent applications in the years 2008-2012; apart from lubelskie in Poland (70.9\% decline), this was the largest decline recorded in the studied area. While capital regions generally rank above the national average, Berlin breaks this trend. In average, both the EU-28 and the Baltic Sea countries experienced negative growth [Eurostat, 2016].

Trademarks reflect the non-technological innovativeness of a sector. They support brand recognition and play an important role in marketing and communication. The European Union trade mark (EUTM) system ensures protection of trade and service marks all across the EU. Among the Baltic Sea countries, Sweden has the highest (208.0 per million inhabitants) and Poland the lowest number of registered trademarks (49.6; for comparison, the EU-28 average is 150.4). At the regional level, these numbers are relatively heterogeneously distributed; the leading regions in both the Baltic Sea region and the EU as a whole are Stockholm (412.6), Hamburg (375.0), Helsinki (317.5) and Copenhagen (303.7), whereas the Polish voivodships warmińsko-mazurskie (18.3) and zachodniopomorskie (52.4) are at the bottom of the list. The highest concentration of registered trademarks can be found in Helsinki (59\% of Finnish EUTM registrations), Copenhagen (48\% of Danish EUTM registrations), Berlin (38\% of Northern German EUTM registrations), and pomorskie (52\% of Northern Polish EUTM registrations) ${ }^{5}$.

Statistics on high-tech industry and knowledge-intensive services contain science, technology, and innovation (STI) data describing their technological intensity. These sectors are regarded as highly competitive and innovative on a global scale. In the following, the focus lies on knowledge-intensive services, since they are more proportionately distributed between the smaller economies of the Baltic Sea region. The share of employment in knowledge-intensive services is especially high in the Scandinavian countries (53-45\%), in Germany it is close to the EU-28 average (40\%), and in the three Baltic states and Poland - below the EU-28 average (ca. 31\% in Poland, 36\% in Latvia). The statistical data reveal a geographical fragmentation between the Scandinavian states on the one hand, Eastern Europe on the other, and Germany in the middle. The three Baltic states showed a growth rate above the EU-28 average. The highest growth rate was recorded in warmińsko-mazurskie, which marked a considerable catching-up process that transformed this voivodship from a region with the lowest employment

5 The data refer to NUTS 2 regions in Northern Germany (Berlin, Brandenburg, Bremen, Hamburg, Mecklenburg-Vorpommern, Lüneburg, Schleswig-Holstein) and Northern Poland (warmińsko-mazurskie, podlaskie, pomorskie, zachodniopomorskie). 
in knowledge-intensive services to a region close to the Polish average. In addition, statistics on high-technology sectors allow to draw some interesting conclusions. Defined as an aggregate of high-technology manufacturing and knowledgeintensive high-technology services, they are smaller in comparison to knowledge-intensive services. In this case geographical fragmentation is less noticeable, with Norway $(4.0 \%)$ and Germany $(4.1 \%)$ ranking close to, Sweden $(4.9 \%)$, Denmark (5.6\%), and Finland (5.9\%) above, and Poland (3.0\%), Latvia (3.3\%), and Lithuania $(2.3 \%)$ below the EU-28 average (4.0\%). Estonia, with the share of 5.1\%, appears to be more of a Northern than Eastern European country, not only ranking third within the studied area, but also witnessing the highest growth in the period of 2008-2012. Again, the Eastern European countries show a growth rate higher than the EU-28 average, which can be attributed to their still emerging high-tech industry. At the regional level, the highest shares of employment in high-technology sectors were recorded in Helsinki (10\%), Hovedstaden (9.7\%), Oslo (8.1\%), and Stockholm $(7.1 \%)$, with only the latter showing a decline since 2008 [Eurostat, 2016].

A similar geographic fragmentation can be observed in the share of human resources in science and technology (HRST) in the overall active population. HRST refers to persons who completed a tertiary level of education or are employed in science and technology sectors [Eurostat, 2016]. Again, the Scandinavian countries of Sweden, Finland, and Denmark rank above the EU average (45\%), this time accompanied by Norway with the highest share of HRST in the active population among the Baltic Sea countries. Germany, on the other hand, although ranking slightly above the EU-28 average, is outperformed by Estonia and Lithuania. The below-average growth rate in Germany (4.2\%) and Denmark (4.9\%) is not necessarily critical, as their HRST shares reflect the European average. Moreover, Norway, Sweden, and Finland not only have the highest share of HRST in the active population, but also record the highest growth rates in the studied area. Estonia once again ranks above the Eastern European average, both in terms of HRST share and its growth rate. In the regional perspective, only Lüneburg experienced a decline. The other German regions, apart from Hamburg, recorded slower growth than the European average. The highest concentration of fast-growing regions is observed in Norway (with an average regional growth of over $9 \%$ ), which is the only country in the studied where all regions ranked above the EU-28 average in terms of HRST share. Poland, where only one of the sixteen examined regions, namely mazowieckie, ranked above the EU-28 average in terms of HRST share, still experienced noticeable development, confirmed by the substantial growth rates recorded in the years 2008-2015.

The same pattern becomes visible when analysing the Regional Innovation Scoreboard (RIS), which measures the innovation performance of 214 European regions [Hollanders, Es-Sadki, Kanerva, 2016] and classifies them either as 


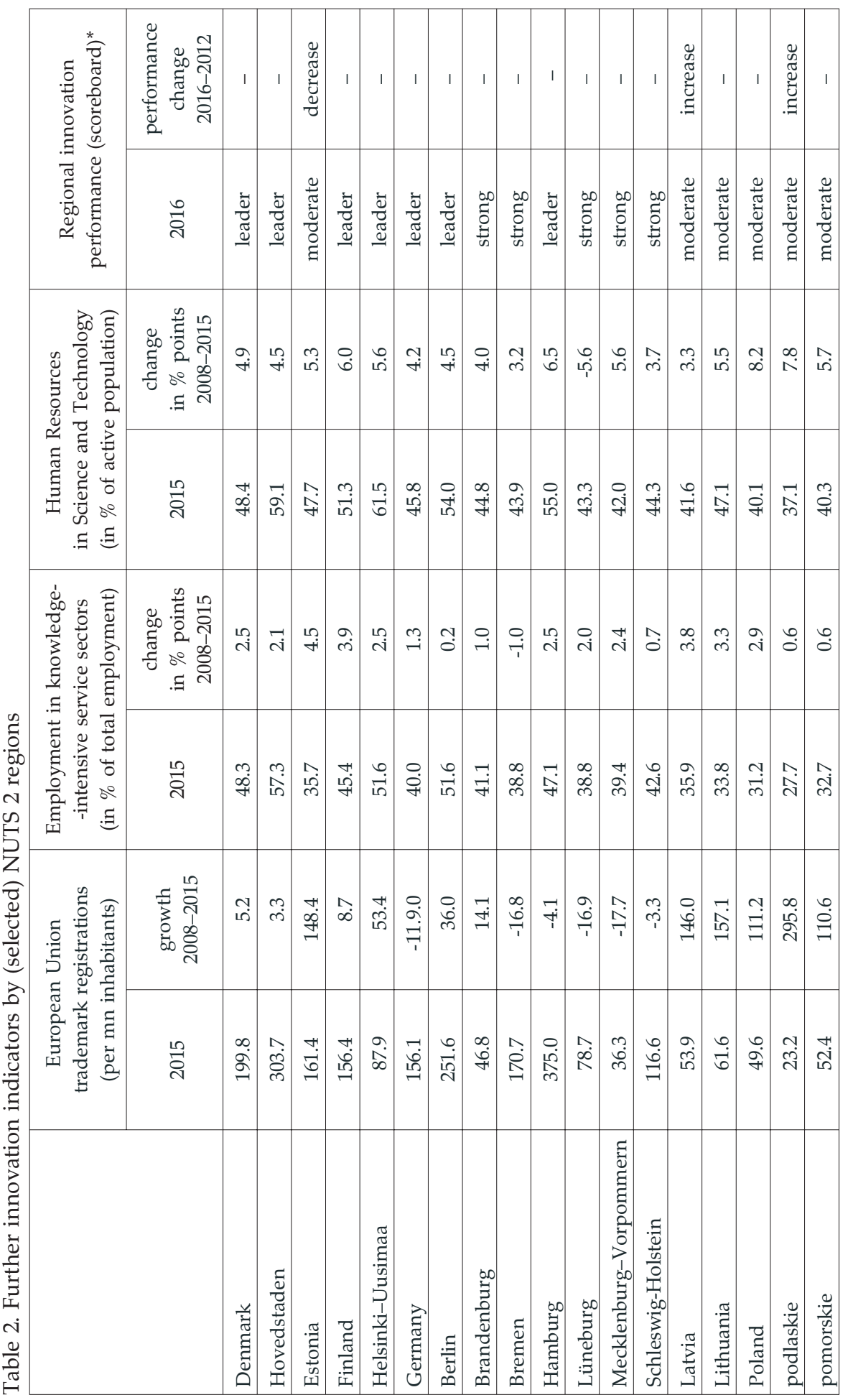




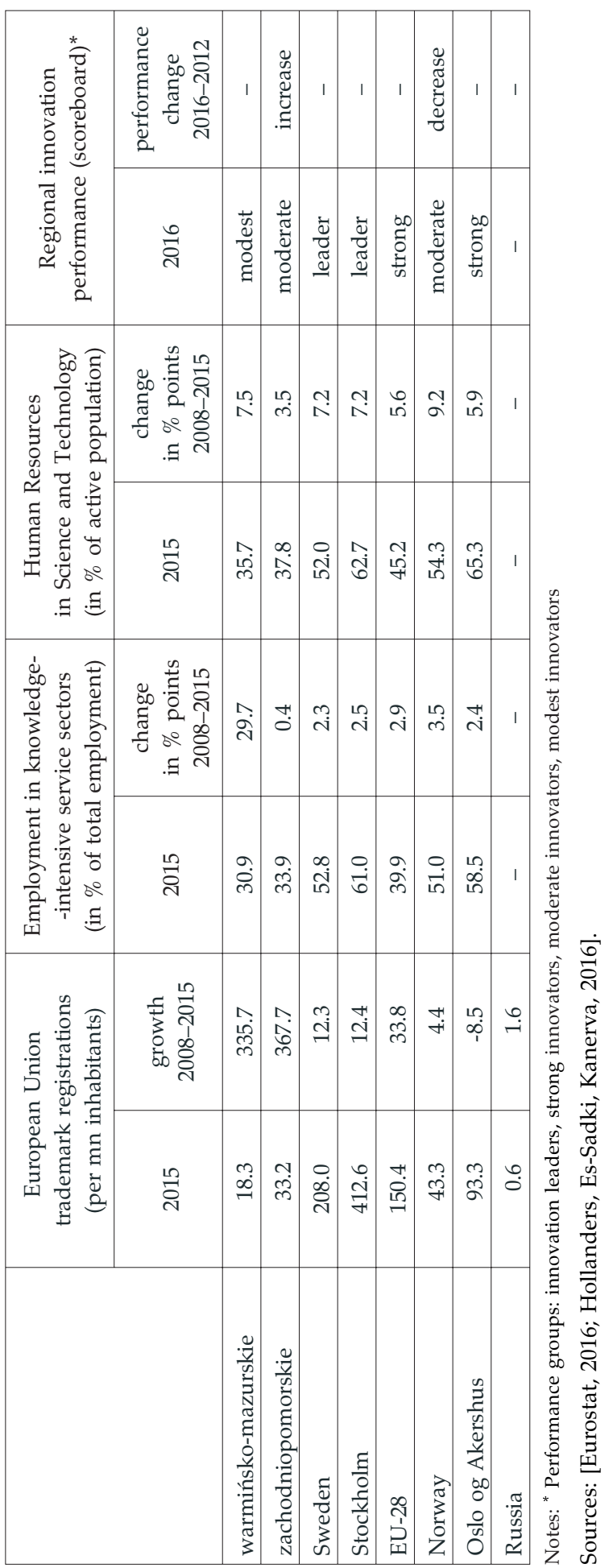


'innovation leaders', 'strong innovators', 'moderate innovators', or 'modest innovators'. Almost all Danish regions are classified as 'innovation leaders', apart from Syddanmark, which is a 'strong innovator'. In Sweden, more than half of the regions are also 'innovation leaders'; interestingly, the capital region of Stockholm is not among them. All Finnish regions are classified as 'strong innovators' with the exception of Helsinki, which is an 'innovation leader'. Norway breaks this positive trend, with Oslo and Trondelag classified as 'strong innovators' and the other regions only as 'moderate innovators'. The Baltic states regions are also considered 'moderate innovators'. Germany occupies a place in the middle of the classification, with both 'innovation leaders' (Hamburg and Berlin) and 'strong innovators'. Poland is the only country in the studied area with several regions classified as 'modest innovators'. In this case, better results were achieved by the regions bordering the Baltic Sea than by the capital regions. In the years 2012-2016, the position of all the regions in the classification has been relatively stable.

\section{Conclusions}

Innovation capabilities highly contribute to the growth and welfare of the European Union. The Baltic Sea countries, although heterogeneous in terms of innovativeness and resource endowment, already greatly advance this development.

The Europe 2020 R\&D targets are challenging and will probably not be reached, just like the analogous targets of the Lisbon 2010 strategy. In the last decade, the EU member states intensified their R\&D activities, largely due to national efforts. The main European innovation leaders are the Scandinavian countries and Germany; the three Baltic states and Poland, on the other hand, rank below the EU-28 average. Obviously, the economic transformation has not yet raised them to the Western European level, but their progress is reflected in specific indicators. That being said, despite the fact that some of the highest growth rates were recorded in the Eastern Baltic Sea countries, most of their regions are still catching up to the western part of the Baltic Sea region. Moreover, capital and city regions tend to outperform most of the other regions in the studied area.

The observed disparities along the east-west axis are expected to decrease in the future. As part of this process, which will most likely take decades, the R\&D capacities of the three Baltic States and Poland will expand and create potential for growth. These economies will profit from their proximity to the established knowledge-based economies, such as Finland and Sweden. One important factor in the transfer of knowledge - due to the growing digitalisation - is the face-to-face contact and cross-border mobility of the labour force guaranteed by the four freedoms of the European Union. 


\section{References}

Blech L., Brandhuber B., Könönen A., Köster R., Lenné T., Reich N., Rohde O., Stiller S., Wedemeier J., 2009, Creative future: Growth potentialities for Baltic cities, http://www. hwwi.org/fileadmin/hwwi/Leistungen/Gutachten/Creative_Future_Screen.pdf [access: 01.09.2017].

EC, 2009, Communication from the Commission to the European Parliament, the Council, the European Economic and Social Committee and the Committee of the Regions concerning the European Union Strategy for the Baltic Sea Region, Action Plan, COM(2009) 248, Brussels.

EC, 2010, Communication from the Commission, Europe 2020: A Strategy for Smart, Sustainable, and Inclusive Growth, $\operatorname{COM}(2010) 2020$ final, Brussels.

Eurostat, 2016, Innovation indicators and further statistical data, http://ec.europa.eu/eurostat/ de [access: 15.09.2016].

Fagerberg J., 2009, Innovation: A guide to the literature, [in:] The Oxford handbook of innovation, eds. Fagerberg J., Mowery D.C., Nelson R.R., Oxford University Press, Oxford, http://www.oxfordhandbooks.com/view/10.1093/oxfordhb/9780199286805.001.0001/ oxfordhb-9780199286805-e-1 [access: 02.09.2017].

Frietsch R., Rammer C., Schubert T., 2015, Heterogeneity of innovation systems in Europe and Horizon 2020, Intereconomics, no. 1.

Hollanders H., Es-Sadki N., Kanerva M., 2016, Regional Innovation Scoreboard 2016, Brussels.

Pelle A., 2015, Mind the GAP: Arguments in favour of judicious constructivism in providing horizon for all, Intereconomics, no. 1.

Pochet P., 2010, What's wrong with EU2020?, Intereconomics, no. 3.

Romer P., 1986, Growth based on increasing returns due to specialization, American Economic Review, no. 2.

Schumpeter J.A., 1950, Kapitalismus, Sozialismus und Demokratie, Francke, Bern.

Stiller S., Wedemeier J., 2016, The future of the Baltic Sea region: Potentials and challenges, HWWI Policy Report, no. 16, http://www.hwwi.org/uploads/tx_wilpubdb/HWWI_ Policy_Report_Nr16_English.pdf [access: 01.09.2017].

J. Wedemeier ( $\bullet$ ) wedemeier@hwwi.org

Hamburg Institute of International Economics, Fahrenheitstraße 1, 28359 Bremen, Germany 